\title{
Plasma Propranolol Levels Associated with Suppression of Ventricular Ectopic Beats
}

\author{
D. J. COLTART D. G. GIBSON, D. G. SHAND
}

British Medical fournal, 1971, 1, 490-491

\section{Summary}

The plasma propranolol levels associated with the abolition of chronic, stable ventricular ectopic beats have been studied. Racemic propranolol (DL) suppressed the ectopic foci at plasma levels of $40-85 \mathrm{ng} / \mathrm{ml}$ in eight patients, but levels of $70-200 \mathrm{ng} / \mathrm{ml}$ were unsuccessful in four patients. Dextro-(D) propranolol levels of $180-310 \mathrm{ng} / \mathrm{ml}$ were ineffective in four patients who had previously responded at levels of 60-75 $\mathrm{ng} / \mathrm{ml}$ of racemic propranolol. The significance of the sympathetic nervous system in the genesis of ectopic beats is discussed. It is concluded that propranolol is clinically effective by virtue of its beta-adrenergic blocking activity.

\section{Introduction}

Propranolol is now well established as an effective drug in the treatment of a variety of ventricular arrhythmias. Its mechanism of action, however, remains uncertain, since in addition to being a beta-adrenergic blocking agent propranolol resembles quinidine in being a potent local anaesthetic and in reducing the rate of rise of the intracellular cardiac action potential without affecting the resting potential or the repolarization time (Dohadwalla et al., 1969). These latter properties, termed "quinidine-like" or "nonspecific," have been associated with suppression of certain experimental arrhythmias, particularly those due to digitalis intoxication in anaesthetized animals. They are, however, found only in vitro at concentrations far greater than those necessary to produce beta-adrenergic blockade and, in addition, are possessed equally by both optical isomers of propranolol, though dextro-propranolol has only onehundredth the beta-adrenergic blocking activity of the laevo form (Barrett and Cullum, 1968).

The present study was designed to investigate the mechanism of antiarrhythmic activity in man by measurement of plasma levels of racemic and dextro-propranolol associated with suppression of stable ventricular ectopic beats, and by comparison of these levels with those previously shown to inhibit tachycardia due to exercise or isoprenaline in normal volunteers (Coltart and Shand, 1970). If the antiarrhythmic effect of the drug was due to its "non-specific" activity, sunnression of ventricular ectopic beats would require very much higher olasma levels than those causing beta blockade, and, in addition, both optical isomers would show equal activity. The results of the present study indicate that this is not the case and that suppression of ventricular ectopic beats anpears to be closely related to beta-adrenergic blockade.

St. Bartholomew's Hospital, London E.C.I

D. J. COLTART, M.B., M.R.C.P., Research Registrar, Department of Cardiology

D. G. GIBSON. M.B., M.R.C.P., Senior Registrar

D. G. SHAND, PH.D., M.R.C.P., Lecturer in Medicine, Division of Clinical Pharmacology (Present address: Vanderbilt University, Nashville, Tennessee)

\section{Methods}

Twelve patients aged 34-69 (mean 52) years were studied; eight were men. All had ventricular ectopic beats which were stable from day to day and which occurred at a frequency of at least one to every four sinus beats. They were unifocal in eight patients, while in the remainder they appeared to originate from more than one site. Their aetiology was not always apparent, though in five there was clinical or cardiographic evidence of chronic ischaemic heart disease. Patients with valvular heart disease, obstructive airways disease, cardiac failure, or recent myocardial infarction were excluded from the study, and none had taken any medication over the preceding two weeks. The nature of the investigation was explained to them, and informed consent was obtained.

The patients were studied supine with electrocardiograph and cuff blood pressure monitored continuously throughout. Normal saline was infused intravenously for an initial control period of 30 minutes. At the end of this time racemic propranolol was administered intravenously at a rate of $1 \mathrm{mg} / \mathrm{min}$ to a total dose of $10 \mathrm{mg}$ or until there was a positive therapeutic response, defined as complete suppression of ectopic beats for a period of at least two minutes. If the procedure was unsuccessful it was repeated on another day, when racemic propranolol was infused at $2 \mathrm{mg} / \mathrm{min}$ to a total dose of $20 \mathrm{mg}$ under identical conditions. In four of the patients who had had a positive therapeutic response to racemic propranolol dextro-propranolol was administered on a separate occasion at $2 \mathrm{mg} / \mathrm{min}$ to a total dose of $40 \mathrm{mg}$. Both drugs were dissolved in normal saline, and the total volume of fluid given did not exceed $30 \mathrm{ml}$ on any occasion. Blood samples were taken at the start of the control period, when suppression occurred, or at the end of the infusion if the procedure was unsuccessful, and plasma levels of propranolol were estimated by a fluorimetric method sensitive to both optical isomers of the drug (Shand et al., 1970). There were no side effects of the investigation.

\section{Results}

The mean frequency of ectopic beats in the control period was 28 per minute, and the maximum variation in ectopic frequency was three ectopic beats in any one-minute period above or below the mean value.

The results are given in the Table. Infusion of racemic propranolol suppressed ventricular ectopic beats in 8 out of the 12 patients, associated blood levels being in the range 40 $85 \mathrm{ng} / \mathrm{ml}(64 \pm 14)$. In no case did ectopic beats reappear within 10 minutes once suppression had occurred. In the four patients in whom suppression did not occur plasma levels of $70-200 \mathrm{ng} / \mathrm{ml}$ had been achieved by the end of the infusion. None of the four patients given dextro-propranolol responded despite blood levels of $180-310 \mathrm{ng} / \mathrm{ml}$, compared with values of only $60-75 \mathrm{ng} / \mathrm{ml}$ of racemic propranolol which had previously caused suppression. Racemic propranolol caused a reduction in sinus rate in all cases-whether the ectopic beats were suppressed or not-which was closely correlated with the plasma level of the drug $(r=-0.79, P<0.001)$. Dextro-propranolol was without significant effect on heart rate. 
Plasma Propranolol Levels (ng/ml) Associated with Ventricular Ectopic Beats

\begin{tabular}{|c|c|c|c|c|c|c|c|c|}
\hline \multicolumn{3}{|c|}{ Case No. } & $\begin{array}{l}\text { Plasma Level of } \\
\text { DL-Propranolol } \\
\text { Associated with } \\
\text { Suppression }\end{array}$ & $\begin{array}{c}\text { Rate Change } \\
\left(\begin{array}{l}0 \\
0\end{array}\right)\end{array}$ & $\begin{array}{c}\text { Plasma Level of } \\
\text { pL-Propranolol } \\
\text { Associated with } \\
\text { Non-suppression }\end{array}$ & $\begin{array}{c}\text { Rate Change } \\
\left(\begin{array}{c}\% \\
\%\end{array}\right)\end{array}$ & $\begin{array}{l}\text { Plasma Level of } \\
\text { D-Propranolol } \\
\text { Associated with } \\
\text { Non-suppression }\end{array}$ & Rate Change \\
\hline $\begin{array}{r}1 \\
2 \\
3 \\
4 \\
5 \\
6 \\
7 \\
8 \\
9 \\
10 \\
11 \\
12\end{array}$ & $\begin{array}{l}\cdots \\
\cdots \\
\cdots \\
\cdots \\
\cdots \\
\cdots \\
\because \\
\cdots \\
\cdots\end{array}$ & $\begin{array}{l}. \\
\cdots \\
\because \\
\cdots \\
\because \\
\because \\
\because \\
\because \\
\cdots\end{array}$ & $\begin{array}{l}60 \\
75 \\
75 \\
60 \\
85 \\
40 \\
50 \\
65 \\
= \\
= \\
-\end{array}$ & $\begin{array}{r}13 \\
16 \\
17 \\
20 \\
18 \\
-9 \\
\cdots 17 \\
20 \\
= \\
=\end{array}$ & $\begin{array}{l}= \\
= \\
= \\
= \\
\overline{110} \\
82 \\
70 \\
200\end{array}$ & $\begin{array}{l}= \\
= \\
= \\
= \\
\overline{2} \\
-19 \\
15 \\
24\end{array}$ & $\begin{array}{l}250 \\
180 \\
310 \\
280 \\
= \\
= \\
= \\
= \\
=\end{array}$ & $\begin{array}{l}-3 \\
-1 \\
11 \\
-2 \\
= \\
= \\
= \\
= \\
=\end{array}$ \\
\hline \multicolumn{3}{|c|}{ Mean \pm S.D. } & $64 \pm 14$ & $-16 \pm 4$ & $115 \pm 51$ & $-20 \pm 4$ & $255 \pm 48$ & $-1 \pm 2$ \\
\hline
\end{tabular}

\section{Discussion}

The patients in the present study were a selected group, since those with digitalis intoxication were excluded by definition, and in none was there evidence of recent myocardial infarction. All were virtually asymptomatic at the time of study, and there was no reason to suspect increased sympathetic activity. Nevertheless, by studying such patients with frequent stable ventricular ectopic beats, and by taking complete suppression as the end point, sampling error due to relatively short monitoring periods was reduced. Prolongation of the study would have increased the possibility of accumulation of active metabolites of propranolol not estimated by the assay procedure (Coltart and Shand, 1970), so that the concentration measured would have no longer reflected the antiarrhythmic activity of plasma. These considerations appeared to outweigh any difficulties in relating plasma concentrations to their effect on receptors during unsteady-state conditions such as arise during a short period of intravenous administration.

Ventricular ectopic beats were suppressed in 8 out of 12 patients with intravenous doses of up to $20 \mathrm{mg}$ of racemic propranolol. This proportion is in line with that in previous reports-where rather smaller doses of the drug were usedof patients with ectopic beats unrelated to acute mvocardial infarction or anaesthesia (Gibson and Sowton, 1969). In two patients (Cases 9 and 12) ectopic beats persisted in spite of plasma levels of propranolol that were very much higher than those at which suppression occurred, suggesting a real difference in the response to symoathetic blockade. All patients whose ectopic beats were abolished had plasma levels significantly lower than $100-150 \mathrm{ng} / \mathrm{ml}$, the level previously shown to be associated with maximal blockade of tachvcardia in normal volunteers inducer bv strenuous exerrice following intravenous administration (Coltart and Shand, 1970).

In the present study there was a close relation between plasma levels of racemic propranolol and the reduction in sinus rate, showing that antiarrhythmic activity appears over the same range of blood levels as those causing beta-adrenergic blockade. These concentrations are less than onehundredth those reauired in vitro to demonstrate local anaesthetic or quinidine-like effects on isolated human cardiac muscle fibres (Coltart and Meldrum, 1970). Significant protein binding by plasma would increase this difference. Further evidence of dissnciation between non-specific effects and antiarrhytbmic activity was the failure of dextropropranolol to inhibit ventricular ectopic beats though very high blood levels were achieved, suggesting that antiarrhyth- mic activity in man is closely related to beta-adrenergic blockade. While it is well recognized that excessive sympathetic stimulation may cause cardiac arrhythmias and that a high response rate to beta-adrenergic blockade has been observed in those associated with halothane anaesthesia or after acute myocardial infarction or open heart surgery (Gibson and Sowton, 1969), the activity of racemic propranolol in the present group of patients in whom the associated reduction in sinus rate was small suggests that blockade of even low levels of sympathetic tone may alter the conditions contributing to the genesis or maintenance of the arrhythmia.

The failure of dextro-propranolol to suppress ventricular ectnoic beats is in line with previously renorted experience with dextro-isomers of beta-adrenergic blocking drugs (Linko et al., 1968). It is at variance, however, with the results of Howitt et al. (1968), who reported that racemic and dextropropranolol had approximately equivalent effects on sunraventricular and ventricular ectopic beats and tachycardia. The reason for this discrepancy is not clear, but it may reflect differences in the aetiology of the arrhythmias studied or the criteria bv which effectiveness was assessed. Nevertheless, the overall results of the present study support the conclusion that propranolol is an antiarrhuthmic drug of clinical importance by virtue of its beta-adrenergic blocking activity, and that its non-specific effects play no more than a minor part.

We are grateful to the phvsicians of St. Bartholomew's Hospital for nermission to studv patients under their care and to Drs. John Hamer and Paul Turner for encouragement.

D. I C. is in rereipt of a research grant kindlv given by Imperial Chemical Industries Ltd. and is the Mary Scharlieb Research Scholar of the Universitv of London 1970-1 and the Cooper and Coventson Research Scholar of St. Bartholomew's Hospital.

\section{References}

Barrett, A. M., and Cullum, V. A. (1968). British fournal of Pharmacology,

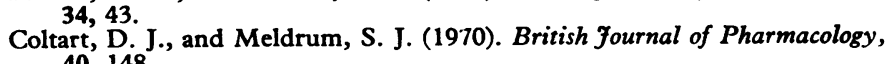
$40,148$.

Coltart, D. J., and Shand, D. G. (1970). British Medical Fournal, 3, 731.

Dohadwalla, A. N., Freedberg, A. S., and Vaughan Williams, E. M. (1969). British fournal of Pharmacolopv, 36, 257.

Gibson, D., and Sowton, E. (1969). Progress in Cardiovascular Disease, $12,16$.

Howitt, G., Husaini, M., Rowlands, D. J., Lozan, F. W. E., Shanks, R. G., and Evans, M. G. (1968). American Heart Fournal, 76, 736.

Linko, E., Ruosteenoja, R., and Sitonen, L. (1968). American Heart fournal,

Shand, D. G., Nuckolls, E. M., and Oates, J. A. (1970). Clinical Pharmacology and Therapeutics, 11, 112. 